\title{
Methods of cultivation and technical coefficients of peanuts in the Bahian Recôncavo
}

\section{Métodos de cultivo e coeficientes técnicos do amendoim no Recôncavo Baiano}

\author{
Fábio Botelho 1* (1) (https://orcid.org/0000-0003-4223-2857) \\ Clovis Pereira Peixoto ${ }^{1}$ (D) (https://orcid.org/0000-0002-6618-1700) \\ Ademir Trindade Almeida' (D) (https://orcid.org/0000-0001-5233-7607) \\ Gabriella Laura Peixoto Botelho' (1) (https://orcid.org/0000-0001-6526-7783)
}

\begin{abstract}
The objective of this study was to collect information about peanut cultivation methods adopted by family farmers in the Bahian Recôncavo (region that surrounds the bay in the state of Bahia, Brazil), using a specific form and also direct information from farmers. An ethnobotanical survey was carried out in the mesoregion of the Bahian Recôncavo in the following municipalities: Conceição do Almeida, Cruz das Almas, Maragogipe, São Felipe, São Felix, Sapeaçú and Laje (Vale do Jequiriçá), where 60 local farmers answered a nonstructured questionnaire about peanut cultivation. The cultivation system was estimated based on technical coefficients related to peanut cultivation in the area evaluated. The peanut cultivation system is carried out by family farmers from the Bahian Recôncavo who employ outdated practices and do not use the required basic steps. The technical coefficients analyzed show that the cultivation of peanut is an unprofitable activity when considering the high cost of production in this region, even though productivity is higher than in the entire state as well as in the Northeast region. Farmers in the Bahian Recôncavo do not consider the actual production costs of peanuts since they use seeds from previous crops and do not account for the labor costs of family members. There is a lack of active and continuous technical assistance to family farmers, not only in relation to the cultivation system, but also the possibility of other destinations for peanuts produced in the region.
\end{abstract}

KEYWORDS: Arachis hypogaea L.; crop diagnosis; family farming.
RESUMO: O objetivo deste estudo foi levantar informaçóes sobre os métodos de cultivo da cultura do amendoim, adotados por agricultores familiares do Recôncavo Baiano, utilizando-se de um formulário específico e de informaçôes diretas dos agricultores. Foi realizado um levantamento etnobotânico nos municípios da mesorregião do Recôncavo Baiano: Conceição do Almeida, Cruz das Almas, Maragogipe, São Felipe, São Félix, Sapeaçú e no município de Laje (Vale do Jequiriçá), onde 60 agricultores foram entrevistados, por meio de um questionário não estruturado, referente ao cultivo do amendoinzeiro no Recôncavo Baiano. A estimativa do sistema de cultivo foi realizada com base em coeficientes técnicos referentes ao cultivo do amendoinzeiro na área de estudo. $\mathrm{O}$ sistema de cultivo do amendoim é realizado por agricultores familiares do Recôncavo Baiano utilizando práticas ultrapassadas, destituídas das etapas básicas necessárias. Os coeficientes técnicos analisados demonstram que o cultivo do amendoinzeiro é uma atividade pouco lucrativa ao se levar em consideração o alto custo de produção nessa região, mesmo a produtividade sendo maior quando comparada com a do estado, assim como com a da regiáo Nordeste. Os agricultores do Recôncavo Baiano não consideram os custos de produção real do amendoim, uma vez que utilizam sementes de cultivos anteriores e não contabilizam os custos de mão de obra dos familiares. Falta aos agricultores familiares assistência técnica atuante e continuada, não só com relaçáo ao sistema de cultivo como também com a possibilidade de outras destinaçôes para o amendoim produzido na região.

PALAVRAS-CHAVE: Arachis hypogaea L.; diagnóstico da cultura; agricultura familiar. 


\section{INTRODUCTION}

Peanut (Arachis hypogaea L.) is an important legume for agriculture worldwide. Because peanut grains have a nice flavor, they can be consumed in natura (raw), being also a major source of oil used in human nutrition as well as in the production of biofuel and even for medical purposes (SANTOS et al., 2010; MARCHI et al., 2011). Furthermore, its leaflets and stems might be used for the production of forage providing a good alternative for cattle feeding (CÂMARA, 2016).

Production of peanut in Brazil during 2016/2017 was 129,300 ha, with an average yield of 3,606 kg.hat and a production of 466,200 $\mathrm{t}$. The largest production is concentrated in the state of São Paulo, whose productivity was $3,666 \mathrm{~kg} \cdot \mathrm{ha}^{-1}$ and production of $422,300 \mathrm{t}$. Bahia is the sixth largest peanut producer in the country and the second in the Northeast region, with an area of $1,500 \mathrm{ha}$, productivity of $942 \mathrm{~kg} \cdot \mathrm{ha}^{-1}$ and production of 1,400 $\mathrm{t}$ (CONAB, 2018).

In northeast of Brazil, peanut is widely grown by small and average farmers that make their living from family farming (GRACIANO et al., 2011). In the Bahian Recôncavo, this crop is considered extremely important for the population, since it is part of the local culture. This is true mainly in June when there is a major festival called "festa junina" (June festivals) and when the main annual yield is harvested in the region, generating a well-accepted income at this period of time (ALMEIDA et al., 2014).

The smaller production of peanut in the northeast of Brazil might be explained by the low level of technology used by these farmers. The use of machines with agricultural implements such as planting, fertilizing, spraying, and harvesting machines are of paramount importance when thinking about the cost/benefit ratio related to peanut crops. This becomes evident when a farmer invests US\$ $1,800.00$ to grow peanut in one hectare in the semiarid region of the northeast of Brazil compared to a cost of US\$500.00 in the state of Sáo Paulo (GOULART et al., 2017). In addition, low investments in technical assistance also make it difficult to improve productivity in the Northeast.

In this context, the need to perform more thorough researches concerning the techniques of peanut cultivation in the Bahian Recôncavo is undoubtful. Therefore, the goal of the present study was to gather information about the methods of peanut cultivation adopted by family farmers in the Bahian Recôncavo, using a specific form and also getting information direct from the farmers.

\section{MATERIAL AND METHODS}

An ethnobotanical survey was carried out in the following municipalities: Conceição do Almeida, Cruz das Almas,
Maragogipe, São Felipe, São Félix, Sapeaçú and Laje (Vale do Jiquiriçá), all located in the Bahian Recôncavo. Sixty farmers with more experience in growing peanuts and residing in the rural area in the municipalities mentioned above were interviewed. One producer per household filled out a questionnaire with 45 questions following a semistructured interview model (ALMEIDA et al., 2014; 2017).

It is important to emphasize that all participants signed a form authorizing the research to be published, according to a provisional decree number 2.186-16 of August 23, 2001, giving them the right to access the results.

Information on peanut crop related to the forms of crop implantation such as sowing frequency (once or twice a year), soil preparation (weeding, plowing and harrowing), correction of the soil, fertilization used (chemical, organic), pests of higher incidence in the area and cultivation treatment during the peanut plant cycle was collected.

The data collected was tabulated according to the categories related to each question, while the percentage frequency was calculated based on the answers. This method expressed the reality about the cultivation system used by the farmers living in the Bahian Recôncavo.

The crop cultivation system was also estimated based on the practices employed by family farmers in the Bahian Recôncavo, defined as a group of producers whose main labor force is constituted by their family members aiming a higher income and better quality of life. This estimate used technical coefficients related to activities performed during the crop cycle based on their costs.

\section{RESULTS AND DISCUSSION}

In general, farmers growing peanuts in the Bahian Recôncavo use similar techniques, where family farming is a predominant characteristic. The crop is not only used as a way of making a living but also for commercialization with the objective of having an additional income, especially for fresh consumption in the form of cooked legumes/pods.

Table 1 shows the information related to the management used by farmers from soil preparation for sowing to cultivation treatments during the peanut cycle.

Soil chemical analysis is a fundamental step that should be performed in the beginning of the process not only when planting peanuts but also any other crop. Regarding this procedure, all farmers stated that they did not have a chemical analysis made before seeding the peanuts (Table 1).

Although this is the type of crop that does not present a high level of nutritional requirements, peanut plants can have their productivity adversely affected by the lack of essential elements for their growth and development (FREIRE et al., 2007). For these authors, soil chemical analysis is considered 
Table 1. Semistructured questionnaire answered by 60 family farmers growing peanuts in the Bahian Recôncavo, Cruz das Almas, 2019.

\begin{tabular}{|c|c|c|c|c|c|c|c|}
\hline Agric. & Soil analysis & Soil preparation & Sowing & Weeding & Fertilization & Pests & Control \\
\hline 1 & No & Weeding, harrowing & March & One & Poultry manure & Caterpillar & Acaricide \\
\hline 2 & No & Plowing & March and August & One & - & Caterpillar & No \\
\hline 3 & No & Weeding & March and August & One & $\begin{array}{c}\text { Chemical } \\
\text { fertilization }\end{array}$ & - & - \\
\hline 4 & No & Weeding, harrowing & March & Two & - & Caterpillar & No \\
\hline 5 & No & Plowing, harrowing & March and July & Two & $\begin{array}{l}\text { Livestock } \\
\text { manure }\end{array}$ & Caterpillar & No \\
\hline 6 & No & Weeding, harrowing & March and August & Two & - & Caterpillar & No \\
\hline 7 & No & Plowing, harrowing & March and August & Two & Foliar fertilizer & Caterpillar & No \\
\hline 8 & No & Weeding, harrowing & March & Two & Poultry manure & Caterpillar & Acaricide \\
\hline 9 & No & Weeding, harrowing & March and August & Two & $\begin{array}{l}\text { Livestock } \\
\text { manure }\end{array}$ & Ant & No \\
\hline 10 & No & Weeding, harrowing & March and August & Two & $\begin{array}{l}\text { Livestock } \\
\text { manure }\end{array}$ & Caterpillar & No \\
\hline 11 & No & Weeding, harrowing & March & Two & $\begin{array}{l}\text { Livestock } \\
\text { manure }\end{array}$ & Ant & No \\
\hline 12 & No & Weeding, harrowing & March & Two & $\begin{array}{l}\text { Livestock } \\
\text { manure }\end{array}$ & - & - \\
\hline 13 & No & Weeding & March & Two & - & Caterpillar & No \\
\hline 14 & No & Plowing, harrowing & March and August & One & $\begin{array}{l}\text { Livestock } \\
\text { manure }\end{array}$ & - & - \\
\hline 15 & No & Plowing, harrowing & March & One & - & Ant & No \\
\hline 16 & No & Plowing, harrowing & March & Two & - & - & - \\
\hline 17 & No & Weeding & March and August & One & - & - & - \\
\hline 18 & No & Plowing, harrowing & March and August & One & - & - & - \\
\hline 19 & No & Plowing, harrowing & March and August & Two & - & Millipede & No \\
\hline 20 & No & Plowing, harrowing & March & One & $10 / 10 / 2010$ & Caterpillar & No \\
\hline 21 & No & Plowing & April & One & - & Caterpillar & No \\
\hline 22 & No & Plowing & March & One & $10 / 10 / 2010$ & Caterpillar & No \\
\hline 23 & No & Plowing & March & One & - & Caterpillar & No \\
\hline 24 & No & Plowing & March & One & - & - & - \\
\hline 25 & No & Plowing & March & Two & - & Millipede & No \\
\hline 26 & No & Plowing & March & Two & Poultry manure & Millipede & No \\
\hline 27 & No & Weeding & March & Two & $\begin{array}{l}\text { Livestock } \\
\text { manure }\end{array}$ & Millipede & No \\
\hline 28 & No & Plowing, harrowing & March and August & One & - & Caterpillar & No \\
\hline 29 & No & Weeding, harrowing & March & One & - & - & - \\
\hline 30 & No & Weeding & March & One & - & Caterpillar & No \\
\hline 31 & No & Weeding & March and August & One & $\begin{array}{l}\text { Livestock } \\
\text { manure }\end{array}$ & Millipede & No \\
\hline 32 & No & Weeding & March & One & $\begin{array}{l}\text { Livestock } \\
\text { manure }\end{array}$ & $\begin{array}{l}\text { Caterpillar/ } \\
\text { millipede }\end{array}$ & No \\
\hline 33 & No & Plowing & March & One & $\begin{array}{l}\text { Livestock } \\
\text { manure }\end{array}$ & Caterpillar & No \\
\hline
\end{tabular}


Table 1. Continuation.

\begin{tabular}{|c|c|c|c|c|c|c|c|}
\hline Agric. & Soil analysis & Soil preparation & Sowing & Weeding & Fertilization & Pests & Control \\
\hline 34 & No & Plowing & March & One & $\begin{array}{l}\text { Livestock } \\
\text { manure }\end{array}$ & $\begin{array}{c}\text { Caterpillar/ } \\
\text { millipede }\end{array}$ & No \\
\hline 35 & No & Weeding & March & Two & Poultry manure & Caterpillar & No \\
\hline 36 & No & Weeding & April & One & - & Millipede & No \\
\hline 37 & No & Weeding, harrowing & March & One & Castor oil cake & $\begin{array}{c}\text { Caterpillar/ } \\
\text { ant }\end{array}$ & No \\
\hline 38 & No & Plowing, harrowing & March and August & One & $\begin{array}{l}\text { Livestock } \\
\text { manure }\end{array}$ & Ant & No \\
\hline 39 & No & Weeding, harrowing & March and August & Two & $\begin{array}{l}\text { Livestock } \\
\text { manure }\end{array}$ & Ant & No \\
\hline 40 & No & Weeding, harrowing & March and August & Two & $\begin{array}{l}\text { Livestock } \\
\text { manure }\end{array}$ & Caterpillar & No \\
\hline 41 & No & Weeding & March & One & $\begin{array}{l}\text { Livestock } \\
\text { manure }\end{array}$ & Ant & No \\
\hline 42 & No & Plowing, harrowing & March & One & - & Millipede & No \\
\hline 43 & No & Harrowing & April & One & - & Millipede & No \\
\hline 44 & No & Plowing & March & One & - & Millipede & No \\
\hline 45 & No & Plowing & March and August & One & $\begin{array}{l}\text { Livestock } \\
\text { manure }\end{array}$ & $\begin{array}{l}\text { Caterpillar/ } \\
\text { millipede }\end{array}$ & No \\
\hline 46 & No & Plowing, harrowing & March & One & $\begin{array}{l}\text { Livestock } \\
\text { manure }\end{array}$ & Caterpillar & No \\
\hline 47 & No & Plowing, harrowing & March & One & $\begin{array}{l}\text { Livestock } \\
\text { manure }\end{array}$ & Caterpillar & No \\
\hline 48 & No & Weeding, harrowing & March and August & Two & $\begin{array}{l}\text { Livestock } \\
\text { manure }\end{array}$ & Caterpillar & No \\
\hline 49 & No & Weeding, harrowing & March and August & One & - & Ant & No \\
\hline 50 & No & Weeding & March and August & Two & $\begin{array}{l}\text { Livestock } \\
\text { manure }\end{array}$ & Ant & No \\
\hline 51 & No & Plowing, harrowing & March and August & One & Poultry manure & Caterpillar & No \\
\hline 52 & No & Weeding, harrowing & March and August & One & - & Millipede & No \\
\hline 53 & No & Plowing, harrowing & March & One & Foliar fertilizer & $\begin{array}{c}\text { Caterpillar/ } \\
\text { millipede }\end{array}$ & No \\
\hline 54 & No & Plowing & April & One & - & Caterpillar & No \\
\hline 55 & No & Plowing, harrowing & March & One & Poultry manure & Caterpillar & No \\
\hline 56 & No & Plowing, harrowing & March & One & $\begin{array}{l}\text { Livestock } \\
\text { manure }\end{array}$ & $\begin{array}{c}\text { Ant/ } \\
\text { millipede }\end{array}$ & No \\
\hline 57 & No & Weeding, Plowing & February and July & One & Foliar fertilizer & - & - \\
\hline 58 & No & Weeding & March and August & Two & $10 / 10 / 2010$ & - & - \\
\hline 59 & No & Weeding & March & One & Super simples & Caterpillar & No \\
\hline 60 & No & Weeding & March and August & One & $10 / 10 / 2010$ & Caterpillar & No \\
\hline
\end{tabular}

one of the most recommended techniques to evaluate the plant nutritional conditions. Peanut plant nutrition might be one of the factors that influences its productivity, since the availability of essential elements to plants such as phosphorus, nitrogen and potassium might promote significant effects on the vegetative and reproductive performance of the crop (COSTA et al., 2017).
Because farmers plant peanuts in small areas and sometimes intercrop them with other perennial plants in their initial stage or even in single areas, the soil analysis is not a concern to them, so soil acidity is not corrected. Therefore, when performed, fertilization is made regardless of the needs of the plant. 
When preparing the soil for sowing, farmers in the region basically use the following techniques: only weeding for subsequent sowing; weeding followed by plowing and sowing; weeding followed by harrowing and sowing; plowing and sowing; plowing followed by harrowing and sowing or harrowing and sowing. Weeding for subsequent sowing is the soil preparation technique employed by 14 farmers (23.3\%), while 15 farmers $(25.0 \%)$ use weeding followed by harrowing, and only one farmer (1.7\%) uses weeding and also plowing, and another farmer only uses harrowing before sowing (1.7\%). Twelve (20.0\%) of them use plowing and 17 (28.3\%) employ plowing plus harrowing before sowing, respectively (Table 1 ).

All participants stated that they sow peanuts in pits causing an unevenness in the crop plant standing, contributing to the low yield in the region as confirmed by GONÇALVES et al. (2004) and SILVEIRA et al. (2013). However, SILVEIRA et al. (2013) concluded that the sowing in pits resulted in a lower yield when compared to sowing in furrows depending on when the seeds were planted.

Peanuts that belong to fastigiata subspecies, botanical variety fastigiata of the Valencia group (CÂMARA, 2016), might be planted up to three times a year because it has a cycle of about 90 days, but not under dry conditions such as those of the Bahian Recôncavo. Thus, its cultivation in this region is difficult because the rainy season usually happens from March to August, with an annual average of $1,170 \mathrm{~mm}$ (ranging from 900 to $1,300 \mathrm{~mm}$ ), while the climate is dry from September to February (SILVA et al., 2015), demanding water supplementation through irrigation. Therefore, the ideal sowing season is in March and the first 10 days of April, which will coincide with the harvest in June, the best period for commercializing peanuts at the time of the June festivals (PEIXOTO et al., 2008).

Of the 60 farmers who participated in the research, 59 sowed peanuts in this period. The remaining 24 (40.7\%) farmers grew peanuts two times a year, planting in March/ August (39\%) and March/July (1.7\%) (Table 1). Only 1 farmer (1.67\%) planted peanuts in February/July.

When assessing two peanut genotypes in two different sowing periods, SILVEIRA et al. (2010) noticed that the highest insolation observed at the end of the peanut cycle when planted in July favored the decrease in grain moisture compared to sowing performed in April, avoiding contamination with fungi. However, planting peanuts in the second semester (July/August) is considered risky because most part of the peanut crop in the Bahian Recôncavo is a dryland system and the rainy days in this period of time tends to decrease, possibly affecting the establishment and later development of plants.

On the other hand, harvesting in June makes the seeds production difficult since at this time the temperatures are low and it rains a lot. However, these conditions do not lead to a lower profit because the production in the area is commercialized for the fresh market (fresh legumes/pods), being cooked and consumed in the festivals held in June (PEIXOTO et al., 2008; ALMEIDA et al., 2014).

SANTOS et al. (2013) found that the ideal moment to harvest the peanut is one of the problems farmers face concerning a maximum yield, since if harvested earlier it might result in harvesting a larger amount of immature vegetables. This action might cause damages especially when the goal is to produce seeds and not grains. Farmers in the Bahian Recôncavo dry the legume in two ways: after removing them from the plants, the legumes are exposed to full sun until they reach the point considered ideal for storage, which varies according to the sunstroke and temperature at which submitted. Another method is to maintain the vegetables on the plants, which are hung in a covered place for drying.

As for fertilization, 23 farmers (38.3\%) did not use any kind of fertilization, stating that they take advantage of the previous fertilization for other types of species made prior to peanut, sowing as well as debris of other plants in the planted area. This debris can be considered as a source of organic fertilization after being revolved through plowing and grading, for instance. Of the 37 farmers that used fertilization, 21 $(56.7 \%)$ used livestock manure, $6(16.2 \%)$ poultry manure and one $(2.7 \%)$ used castor oil cake. As for the type of fertilizers used, 6 farmers $(16.2 \%)$ used this source (chemical fertilizer, 10-10-10, Supersimples) and $3(8.1 \%)$ used foliar fertilizer (Table 1). Both manure and fertilizers are used before or after planting the seeds.

Studies aimed at investigating the best fertilization for peanut plants grown under edaphoclimatic conditions of Northeast Brazil are not frequently observed. Based on this goal, LEITE et al. (2015) evaluated the effect of organic fertilization using castor oil cake and goat manure in the state of Paraíba and noticed that better results were achieved when using a maximum dose of goat manure as well as better agronomic features of the BR1 peanut cultivar from the Valencia group.

COSTA et al. (2017) observed satisfactory results in terms of peanut pods and grain yield in Missão Velha, state of Ceará. when using a chemical fertilization $\left(500 \mathrm{~kg} \cdot \mathrm{ha}^{-1}\right.$ of the 4-14-8 fertilizer), as sources of NPK.

Another important chemical element for peanut crop is potassium. In a study performed by SOUSA et al. (2013), it was proven that fertilization with potassium-based fertilizers is considered an alternative to increase crop productivity, since the use of different doses of $\mathrm{K}_{2} \mathrm{O}$ promoted higher yield of peanut plants in the edaphoclimatic conditions in Fortaleza, state of Ceará.

In relation to cultivation treatments, 39 farmers $(65 \%)$ only performed one weeding throughout the crop cycle, while the remaining 21 (35\%) preferred to perform two (Table 1). The authors noticed that the chemical method (herbicides) was not used to control weeds in this study. This causes a higher cost, since paying a daily wage for weeding is one of the most expensive activities in the peanut production system. 
The use of preemergent herbicides is common in peanut cultivation in the state of São Paulo (BARBOSA et al., 2014; LUVEZUTI et al., 2014). Some researches were performed with the goal of testing the effect of herbicides on peanut plants in the Bahian Recôncavo. Alachlor, pendimethalin and trifluralin were the herbicides used (PEIXOTO et al., 2002; 2010a; 2010b). The authors found out that the herbicides tested did not promote satisfactory effects on the growth and development of peanut plants. However, new researches in this context are required to recommend herbicides that shows a favorable action controlling weeds and those that do not injury the peanut plant.

The occurrence of pests and diseases is quite common in peanut plants in Brazilian regions where they are grown. In the Bahian Recôncavo, the crop is also affected by diseases especially in the leaves at the end of their cycle; however, they do not result in significant damages regarding productivity. In terms of pests, the farmers who participated in this research reported that the plants have been attacked by soybean caterpillar (Anticarsia gammatales), armyworm (Spodoptera spp.), leafcutter ants (genera Atta and Acromyrmex) and millipede (Orthomorpha coarctata).

The farmers reported attacks of caterpillars to some crops $(52 \%)$ in the past, showing that this is not a recurring problem in consecutive years, and it can be considered an outbreak that will not cause significant damage to the crop if controlled early. On the other hand, $25 \%$ of the participants confirmed that the plants were attacked by millipede, which causes damages to the seeds after harvesting, resulting in the lack of uniformity in the field crop as defined by GARCIA; CAMPOS (2001). It was noted that the presence of millipede is concentrated in Maragogipe, São Felipe and São Félix, according to the data collected from 60 farmers.

As for ants, $18 \%$ of the farmers stated their plants were attacked by these insects, but did not report concerning economic damages, once a daily monitoring at the beginning of the cycle is good enough to control this issue (Table 1). According to $7 \%$ of the farmers, caterpillar and millipede might attack peanut plants in the same year, affecting the peanut yield in a more significant way.

To control these pests, only 2 farmers (3.3\%) confirmed that they used the insecticide acaricide to control caterpillars, while the others $(96.7 \%)$ stated that the attack of these insects does not result in considerable damage to the peanut tree. Therefore, the application of a pesticide would not be required, especially because the increase in the rainfall index (common from March to June) reduces the incidence of caterpillars. In the case of millipedes, farmers did not use any control methodology and ended up having problems with this pest, especially with regard to the decrease in crop productivity, leading to a lower seed germination and seedling emergence.

The millipede control can be performed by applying insecticides in the seeds or spraying the plants, with active ingredients belonging to the group of the carbamate and phenylpyrazole or fipronil (ÁVILA, 2017).

The most recommended cultivars for the Bahian Recôncavo are those that belong to the Valencia group, because they have characteristics that provide a good growth and development of plants in the endaphoclimatic conditions of the region. In addition, there is a preference for cultivars that are not intended for the mechanized cultivation system. In this sense, studies about peanut plants carried out in the Bahian Recôncavo showed that farmers preferred to use the cultivar Vagem Lisa (GONÇALVES et al., 2004; ALMEIDA et al., 2017).

As already evidenced in this study, the Bahian Recôncavo is characterized as a region where family farming is predominant and where crops are planted in small areas mainly cultivations such as citrus, cassava, yams, tobacco, corn and peanut (GONÇALVES et al., 2004), besides cattle raising, which is a larger segment adopted by wealthier producers.

As for the area chosen for cultivation, peanuts show a better performance in soils with a sand texture because it improves their growth and development. It also facilitates the penetration of gynophore and avoid loses during harvesting, mainly when the soil is dry increasing the possibility of disrupting the peduncle common in clay soils. Soils with a lot of organic matter are not recommended because it can imply in a large growth of the plant and consequently a decrease in legume production. An important aspect about the areas used for peanut cultivation in the Bahian Recôncavo is the use of intercropping systems with crops in their initial phase of implantation, mainly citrus, yam and corn (ALMEIDA et al., 2017).

Studies about special spacing and spatial arrangements were performed in the Bahian Recôncavo in order to research how to get a higher yield of the peanut plant in local conditions (GONÇALVES et al., 2004; PEIXOTO et al., 2008; SILVEIRA et al., 2010; 2015). However, although the results evidenced better productivity when employing sowing in furrows, farmers in this region still insist on sowing peanut in irregularly spaced pits (ALMEIDA et al., 2017).

Based on the results found in the present study and also the experience of the farmers over the years in the Bahian Recôncavo, the construction of a cultivation system that represents the modus operandi of farmers in the region was considered relevant to report the main activities carried out in the peanut crop. Thus, the authors decided to show data related to peanut cultivation costs in the area (Table 2).

Peanut is mainly planted in the rainy season to meet the demand for the consumption of green peanuts (before its complete maturation), whose pods are cooked after harvesting during the festivals in June, which is the main cultural manifestation in the northeast of Brazil.

During this period, most producers rent tractors (US\$ 14.00/h) that will be used for the soil preparation after harvesting other crops such as cassava and yams, or even peanuts. Assuming that it is necessary to spend $4 \mathrm{~h}$ 
Table 2. Technical coefficients or cost of peanut production (US\$ ha ${ }^{-1}$ ) in the Bahian Recôncavo for the cultivation of the cultivar Vagem Lisa. Cruz das Almas, 2019.

\begin{tabular}{|c|c|c|c|c|}
\hline Specifications & Unity & Quantity & Price per unit (US\$) & Total (US\$) \\
\hline Plowing & Hourly rate.tractor ${ }^{-1}$ & 4 & 14.00 & 56.00 \\
\hline Harrowing & Hourly rate.tractor ${ }^{-1}$ & 2 & 14.00 & 28.00 \\
\hline Seeds & Liter & 120 & 2.00 & 240.00 \\
\hline Fertilization & Ton $\cdot h^{-1}$ & 7 & 30.00 & 210.00 \\
\hline Pitting & Worker.day ${ }^{-1}$ & 6 & 10.00 & 60.00 \\
\hline Sowing & Worker.day ${ }^{-1}$ & 6 & 10.00 & 60.00 \\
\hline Weeding and hilling & Worker.day ${ }^{-1}$ & 18 & 10.00 & 180.00 \\
\hline Manual harvesting & Worker.day ${ }^{-1}$ & 8 & 10.00 & 80.00 \\
\hline Threshing & "Quartas" & 252 & 1.00 & 252.00 \\
\hline TOTAL COST & & & & $1,166.00$ \\
\hline
\end{tabular}

for plowing and $2 \mathrm{~h}$ for grading for an area of $1 \mathrm{ha}$, the farmer spends on average US\$ 84.00 for soil preparation and subsequent sowing (Table 2).

Storing their own peanut seeds to be used in future cultivations is a common practice among the farmers (PEIXOTO et al., 2015). However, if needed, farmers have to buy seeds from other storing places located in the same region or even seeds coming from farmers markets and stores that sell agricultural products. In case the purchase of seeds is needed, the bag of pods is sold at an average price of US $\$ 40.00$, with a yield of around $20 \mathrm{~L}$ of seeds per bag, resulting in an estimated price of US $\$ 2.00$ per liter of seeds. Considering that it takes about $120 \mathrm{~L}$ of seeds to sow 1 ha of peanuts, the investment would be US\$240.00 (Table 2).

During the planting process, the expenses include daily wages for workers during pitting and then sowing. In this case, individuals are paid for 6 days of work (pitting and sowing). When considering the daily rate of US\$10.00, the total cost would be US\$ 120.00 per hectare (Table 2).

As verified by this study, on average $62 \%$ of the farmers who participated in the research performed some type of fertilization. Most of them preferred to use organic fertilization with livestock and poultry manure. So, in this case, estimating the need for $7 \mathrm{t} \cdot \mathrm{ha}^{-1}$, and assuming a cost of US\$ $30.00 \cdot \mathrm{t}^{-1}$, the total cost would be US\$ 210.00 per hectare (Table 2 ).

Peanut weeding and ridging cost US\$180.00 per hectare, if considering 18 daily wages (US\$ 10.00/day) (Table 2).

As for the harvesting process, it is possible to observe that the cost would be US\$ 80.00 (total of US\$ 10.00 per 8 days of work) during the process of peanut digging. Furthermore, there is also the threshing, which is the process of separating the seeds from the pod right after the digging, where the farmers pay US $\$ 1.00$ for the "quarta" of threshed pods, spending US\$252.00 for 252 "quartas" per hectare (Table 2). A "quarta" is a container used in the Bahian Recôncavo as a measure that holds 25-30 L of pods (ALMEIDA et al., 2017).
Most farmers sell their products to middlemen or intermediary individuals in their properties. According to ALMEIDA et al. (2017), based on the data collected from 60 farmers that participated in this study, the average yield is about 57 bags of four "quartas" per hectare. Under these conditions, the total cost of production (US\$1,166.00) divided by the number of bags harvested ( 57 bags) is equivalent to an average of US\$ 20.40 per bag. Thus, the farmer would only have a profit if selling the produce for a price higher than US\$20.40, which is not always possible since the price of peanut generally fluctuates because of the increased demand close to the festival in June. The yield considered was $2,565 \mathrm{~kg} \cdot \mathrm{ha}^{-1}$ and the average weight of each bag of immature peanut was $45 \mathrm{~kg}$.

However, based on the findings of a study performed by ALMEIDA et al. (2017), all farmers interviewed stored seeds to use for future planting, being able to save US\$180.00 (cost of seeds described in the technical coefficient in this present study showed at Table 2). This is also explained by the fact that the producer keeps a small area of the field for the full maturation of the pods, whose seeds will be stored. Thus, when the expense with the purchase of seeds in not considered, the production cost will be US\$986.00, where the average price per bag of produced peanuts will be US\$17.20. Consequently, every market price above this figure will mean a profit for the farmer when growing peanuts.

Considering that the data collected represent the reality of the Bahian Recôncavo, it can be stated that its productivity is significantly higher than that of the state as a whole $\left(942 \mathrm{~kg} \cdot \mathrm{ha}^{-1}\right)$ as well as in the Northeast region $\left(1,601 \mathrm{~kg} \cdot \mathrm{ha}^{-1}\right)$. It is important to emphasize that peanut cultivation can reduce the economic risks related to the crop by promoting a decrease in production costs, mainly by adopting mechanization in soil preparation, sowing, weeding and ridging and harvesting, as previously mentioned. This activity would become more competitive and more profitable if these practices were adopted. 


\section{CONCLUSIONS}

The peanut cultivation system is carried out by family farmers from the Bahian Recôncavo that use outdated practices and do not employ the basic necessary stages, such as sowing in furrows instead of pits and mechanical harvesting instead of manual.

The technical coefficients analyzed show that the cultivation of peanut is an unprofitable activity when considering the high cost of production in the Bahian Recôncavo, even though productivity is higher than in the state of Bahia as well as in the Northeast region.

Farmers in the Bahian Recôncavo do not consider the actual production costs of peanuts since they use seeds from previous crops and do not account for the labor costs of family members.

There is a lack of active and continuous technical assistance to family farmers, not only in relation to the cultivation system, but also the possibility of other destinations for peanuts produced in the region.

ACKNOWLEDGEMENTS: Not applicable.

FUNDING: This work did not receive any specific grant from funding agencies in the public, commercial, or not-for-profit sectors.

CONFLICTS OF INTEREST: All authors declare that they have no conflict of interest.

ETHICAL APPROVAL: Not applicable.

AVAILABILITY OF DATA AND MATERIAL: The datasets generated and/or analyzed during the current study are available from the corresponding author on reasonable request.

AUTHORS' CONTRIBUTIONS: Conceptualization: Peixoto, C.P. Formal analysis: Almeida, A.T. Methodology: Botelho, F. Supervision: Peixoto, C.P. Validation: Peixoto, C.P. Visualization: Botelho, F.; Peixoto, C.P.; Almeida, T.A.; Botelho, G. Writing - original draft: Botelho, F.; Peixoto, C.P.; Almeida, T.A.; Botelho, G. Writing - review \& editing: Botelho, F.; Peixoto, C.P.; Almeida, T.A.; Botelho, G.

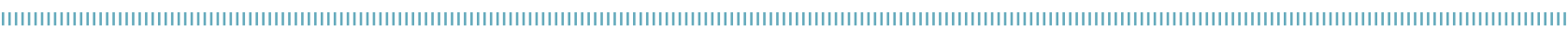

\section{REFERENCES}

ALMEIDA, T.A.; PEIXOTO, C.P.; BLOISI, L.F.M.; OLIVEIRA, J.S.; POELKING, V.G.C. Avaliação morfológica e produtiva de amendoim produzido por pequenos agricultores do Recôncavo da Bahia. Revista Caatinga, Mossoró, v.27, n.3, p.150-159, 2014. Available from: https://periodicos.ufersa.edu.br/index.php/caatinga/article/ view/3694/pdf_149. Access on: 14 Oct. 2020.

ALMEIDA, A.T.; PEIXOTO, C.P.; POELKING, V.G.C.; BLOISI, L.F.M.; SANTOS, J.M.S.; SANTOS, A.M.P.B. Ethnobotany of the peanut in Recôncavo of Bahia, Brazil. Bioscience Journal, Uberlândia, v.33, n.2, p.371-380, 2017. https://doi.org/10.14393/BJ-v33n2-33069

ÁVILA, C.J. Piolhos-de-cobra. In: Pragas da soja: conheça e previna-se. Dourados: Embrapa Agropecuária Oeste, 2017. Available from: https://pragas.cpao.embrapa.br/views/praga. php?id=28. Access on: 1 Jun. 2019.

BARBOSA, R.M.; VIEIRA, B.G.T.L.; MARTINS, C.C.; VIEIRA, R.D. Qualidade fisiológica e sanitária de sementes de amendoim durante o processo de produção. Pesquisa Agropecuária Brasileira, Brasília, v.49, n.12, p.977-985, 2014. https://doi.org/10.1590/ So $100-204 \times 2014001200008$

CÂMARA, G.M.S. Plantas oleaginosas - a planta de amendoim. Departamento de Produção Vegetal da Universidade de São Paulo (USP)/ESALQ, 2016. 20p.
COMPANHIA NACIONAL DE ABASTECIMENTO (CONAB). Décimo levantamento de acompanhamento da safra brasileira de grãos 2017/2018. 2018. Available from: https://www.conab.gov.br/ info-agro/safras/graos/boletim-da-safra-de-graos/item/downlo ad/21088_8ca248b277426bb3974f74efaOOabab6. Access on: 14 Oct. 2020.

COSTA, T.B; SILVA, F.E.; PENHA FILHO, N.; LOPES, N.S.; CAMARA, F.T. Resposta à adubação de duas cultivares de amendoim em dois sistemas de semeadura. Agrarian Academy, Centro Científico Conhecer, Goiânia, v.4, n.8, p.240-248, 2017. https://doi. org/10.18677/Agrarian_Academy_2017b25

FREIRE, M.L.F.; BELTRÃO, N.E.M.; RAO, T.V.R.; MENEZES, H.E.A. Análise de crescimento não-destrutiva do amendoinzeiro submetido a doses de $\mathrm{CaSO}_{4}$ e $\mathrm{P}_{2} \mathrm{O}_{5}$. Revista Brasileira de Ciências Agrárias, Recife, v.2, n.3, p.193-199, 2007. https:// doi.org/10.5039/agraria.v2i3a42

GARCIA, F.R.M.; CAMPOS, J.V. Biologia e controle de artrópodes de importância fitossanitária (Diplopoda, Symphyla, Isopoda), pouco conhecidos no Brasil. Biológico, São Paulo, v.63, n.1/2, p.7-13, 2001. Available from: http://www.biologico.sp.gov. br/uploads/docs/bio/v63_1_2/garcia.pdf. Access on: 14 Oct. 2020. 
GONÇALVES, J.A.; PEIXOTO, C.P.; LEDO, C.A.D.S.; PINTO, M.D.F.D.S.; SAMPAIO, H.S.D.V.; SAMPAIO, L.S.V.; ALMEIDA, N.S. Componentes de produção e rendimento de amendoim em diferentes arranjos espaciais no Recôncavo Baiano. Revista Brasileira de Oleaginosas e Fibrosas, Campina Grande, v.8, n.2-3, p.801-812, 2004.

GOULART, D.F.; ALMEIDA, R.P.; RESENDE, K.C.; COSTA, F.A.M.; BEZERRA, J.R.C. O Desafio da estruturação da cadeia produtiva do amendoim no semiárido do Nordeste. Organizações Rurais $\odot$ Agroindustriais, Lavras, v.19, n.1, p.47-59, 2017. https://doi. org/10.21714/2238-68902017v19n 1 p047

GRACIANO, E.S.A.; NOGUEIRA, R.J.M.C.; LIMA, D.R.M.; PACHECO, C.M.; SANTOS, R.C. Crescimento e capacidade fotossintética da cultivar de amendoim BR 1 sob condições de salinidade. Revista Brasileira de Engenharia Agrícola e Ambiental, Campina Grande, v.15, n.8, p.794-800, 2011 . https://doi.org/10.1590/ S1415-43662011000800005

LEITE, Y.S.A.; VÉRAS, M.L.M.; MELO FILHO, J.S.; MELO, U.A.; COSTA, F.X. Resposta do amendoim (Arachis hypogaea L.) a diferentes fontes e doses de adubação orgânica. Agropecuária Técnica, Areia, v.36, n. 1, p.229-239, 2015. Available from: https://periodicos.ufpb.br/ ojs/index.php/at/article/view/24917. Access on: 14 Oct. 2020.

LUVEZUTI, R.A.; BACHA, A.L.; ALVES, P.L.C.A; PAVANI, M.C.M.D; NEPOMUCENO, M.P. Eficácia de herbicidas no controle de plantas daninhas e seletividade na cultura do amendoim Runner IAC 886. Revista Brasileira de Herbicidas, Londrina, v. 13, n.3, p.207-215, 2014. https://doi.org/10.7824/rbh.v13i3.290

MARCHI, J.L.; CICERO, S.M.; GOMES JUNIOR, F.G. Utilização da análise computadorizada de plântulas na avaliação do potencial fisiológico de sementes de amendoim tratadas com fungicida e inseticida. Revista Brasileira de Sementes, Londrina, v.33, n.4, p.652-662, 2011 . https://doi.org/10.1590/ SO101-31222011000400007

PEIXOTO, M.F.S.P.; SAMPAIO, L.S.V; PEIXOTO, C.P.; SAMPAIO, H.S.V.; SOUZA, R.A.S.; MENESES, C.G.S.; JESUS, J.G.M.N. Herbicidas alachlor, pendimethalin e trifluralin na nodulação e crescimento inicial de plantas de amendoim. Revista Brasileira de Herbicidas, Londrina, v.3, n.2-3, p.139-144, 2002. https://doi.org/10.7824/rbh.v3i2-3.386

PEIXOTO, C.P.; GONÇALVES, J.A.; PEIXOTO, M.F.S.P.; CARMO, D.O. Características agronômicas e produtividade de amendoim em diferentes espaçamentos e épocas de semeadura no Recôncavo Baiano. Bragantia, Campinas, v.67, n.3, p.673-684, 2008. https://doi.org/10.1590/S0006-87052008000300016

PEIXOTO, M.F.S.P.; PEIXOTO, C.P.; SAMPAIO, L.S.V.; SAMPAIO, H.S.V.; SOUZA, R.A.S.; ALMEIDA, J.R.C. Ação do herbicida alachlor na microbiota do solo, nodulação e rendimento de plantas de amendoim. Revista Scientia Agraria Paranaensis, Marechal Cândido Rondon, v.9, n.2, p.60-70, 2010a. Available from: http://saber.unioeste.br/index. php/scientiaagraria/article/view/4579. Access on: 14 Oct. 2020.
PEIXOTO, M.F.S.P.; BORGES, V.P.; BORGES, V.P.; PEIXOTO, C.P. Ação do trifluralin na micorrização e crescimento de plantas de amendoim (Arachis hypogaea L.). Planta Daninha, Viçosa, v.28, n.3, p.609-614, 2010b. https://doi.org/10.1590/ So $100-83582010000300018$

PEIXOTO, C.P.; BLOISI, F.M.; POELKING, V.G.C; OLIVEIRA, J.S.; ALMEIDA, A.T.; CRUZ, T.V. Divergância genética e correlação fenotípicas em genótipos de amendoim do grupo Valencia, tipo Vagem Lisa, no Recôncavo Baiano. Revista Magistra, Cruz das Almas, v.27, n. 1, p. 145-154, 2015.

SANTOS, T.S.; ALMEIDA, F.A.C.; SUASSUNA, T.M.F.; COUTINHO, W.M.; ALMEIDA, P.B.A. Resposta de sementes de amendoim a diferentes doses de radiação gama $\left({ }^{60} \mathrm{Co}\right)$. Revista Brasileira de Engenharia Agrícola e Ambiental, Campina Grande, v. 14, n.10, p.1074-1078, 2010. https://doi.org/10.1590/S1415-43662010001000008

SANTOS, E.P.; SILVA, R.P.; BERTONHA, R.S.; NORONHA, R.H.F.; ZERBATO, C. Produtividade e perdas de amendoim em cinco diferentes datas de arranquio. Revista Ciência Agronômica, Fortaleza, v.44, n.4, p.695-702, 2013. https://doi.org/10.1590/ S1806-66902013000400005

SILVA, E.J.; SILVA, P.C.C.; AMORIM, F.F.; BRITO, R.B.F.; PAMPONET, B.M.; REZENDE, J.O. Atributos físicos e químicos de um Latossolo Amarelo distrófico coeso e crescimento radicular de Brachiaria decumbens submetido à subsolagem e fertilização. Comunicata Scientiae, Bom Jesus, v.6, n.4, p.385-395, 2015. https://doi. org/10.14295/cs.v6i4.484

SILVEIRA, P.S.; PEIXOTO, C.P.; LEDO, C.A.S.; LIMA, V.P.; SANTOS, A.P.S.; NAKAGAWA, J. Alocação de fitomassa e índice de colheita de amendoim em diferentes épocas e densidades de semeadura. Revista Magistra, Cruz das Almas, v.27, n.3/4, p.367-375, 2015. Available from: https://magistraonline. ufrb.edu.br/index.php/magistra/article/view/404. Access on: 15 Oct. 2020.

SILVEIRA, P.S.; PEIXOTO, C.P.; LEDO, C.A.S.; PASSOS, A.R.; BLOISI, A.M.; BORGES, V.P. Componentes de produção de amendoim em diferentes épocas de semeadura e densidades de plantas. Revista Magistra, Cruz das Almas, v.25, n.3/4, p.182-190, 2013.

SILVEIRA, P.S.; PEIXOTO, C.P.; PASSOS, A.R.; SILVEIRA, T.S. Produtividade do amendoim em diferentes épocas de semeadura e com diferentes densidades de plantas no recôncavo Sul Baiano. Revista Brasileira de Oleaginosas e Fibrosas, Campina Grande, v. 14, n.3, p. $115-123,2010$.

SOUSA, G.G.; AZEVEDO, B.M.; OLIVEIRA, J.R.R.; MESQUITA, T.O.; VIANA, T.V.A.; Ó, L.M.G. Adubação potássica aplicada por fertirrigação e pelo método convencional na cultura do amendoim. Revista Brasileira de Engenharia Agrícola e Ambiental, Campina Grande, v.17, n. 10, p.1055-1060, 2013. https://doi. org/10.1590/S1415-43662013001000005 